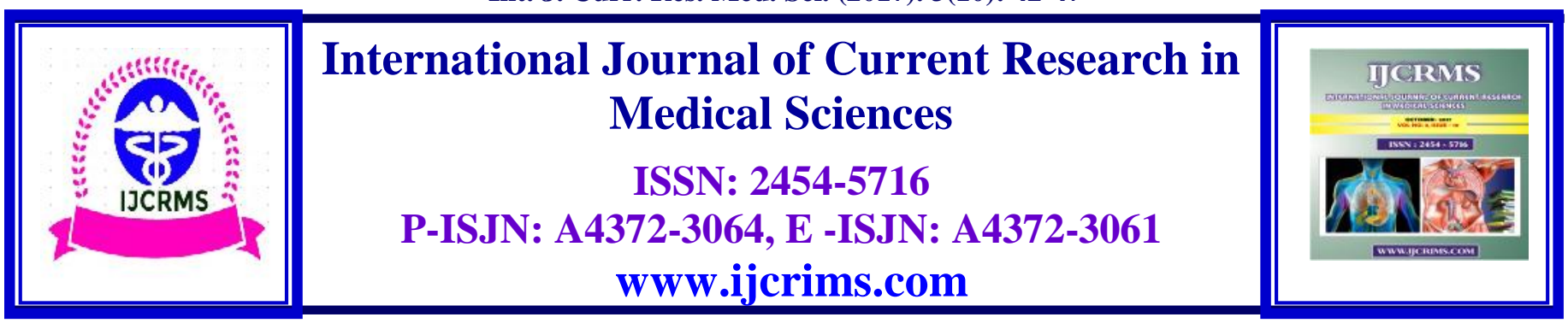

DOI: http://dx.doi.org/10.22192/ijcrms.2017.03.10.008

\title{
Serum Copper and Zinc levels in Type 2 Diabetes Mellitus Patients in Kassala State
}

\author{
*11Mubarak Eissa Musa \\ *11 Abdaleelah ALshaikh Koko \\ *11Sara Muawia Mohammed \\ *11Esraa Saif ALdean Ibrahim \\ $*^{1}$ Department of Clinical Chemistry, Medical Laboratory Science program, \\ Faculty of Medicine and Health science Kassala University, Sudan \\ *22 Abdelrahman Mohamed Sid Ahmed \\ $*^{2}$ Department of Clinical Chemistry, Medical Laboratory Science program, \\ Faculty of Medicine and Health science Kassala University, Sudan \\ *33 Khadega Suleiman Mohammed Zarroug \\ Department of Microbiology and Parasitology, Faculty of Medicine and Health Science, \\ Kassala University, Sudan \\ ${ }^{*}{ }^{4}$ Hutheiefa Ibrahim Younis Mohammed \\ * Rowa ALaa ALdeen Hussein Ahmed \\ ${ }^{*}$ Department of Clinical Chemistry, Faculty of Medical Laboratory Science, Elrazi University, \\ Khartoum, Sudan
}

\section{Abstract}

Introduction: Diabetes Mellitus is a metabolic disease char-acterised by hyperglycemia due to defective insulin secretion or action. Levels of trace elements like Copper and Zinc have been found to be altered in this disorder. Theses might have some role in progression of this disease. Purpose of the study was to estimate serum zinc and copper levels in type 2 diabetes mellitus patients with and without micro-vascular complication and to compare with that of healthy individuals. And also, to identify the inter-relationship among these.

Material and methods: A cross sectional study was carried in at Kassala teaching hospital during the period from March to October 2017, diabetic type 2 patients (30) and control (20), selected cases of confirmed type 2 diabetes mellitus (T2DM) patients, and healthy controls were included in this study. Serum copper and zinc levels were estimated in the serum of these patients and healthy control by using by atomic absorption.

Results: Serum $\mathrm{Zn}$ levels were lower for T2DM cases with $(P$-value $=0.007)$. While serum Copper was highest among cases of T2DM $(P$-value $=0.012)$. When compared to control groups

Conclusion: Altered levels of trace elements $\mathrm{Zn}$ and $\mathrm{Cu}$ are found to be an important predisposing factors for diabetic patients for developing complications.

Keywords: T2DM Type 2 Diabetes mellitus, Zn Zinc, cu Copper 


\section{Introduction}

"Diabetes mellitus" describes a metabolic disorder of multiple etiology, which is characterized by chronic hyperglycemia, with disturbances of carbohydrate, fat and protein metabolism, which result from defects in insulin secretion, insulin action, or both, Diabetes mellitus affects 200 million people worldwide ${ }^{(1)}$. Type 2 diabetes is due to insulin resistance and/or insulin secretory defects, and accounts for almost $90 \%$ of all diabetic cases ${ }^{(2)}$.

The persistence of these metabolic disturbances lead to permanent and irreversible functional and structural changes in the cells of the body which in turn lead to the development of "diabetic complications", characteristically affecting, the cardiovascular system, eye, kidney and nervous system mainly ${ }^{(3)}$.

The Patients with diabetes mellitus are at increased risk for cardiovascular diseases, thus cardiovascular complications are the leading cause of diabetes-related morbidity and mortality (4).

Direct associations of trace and macro elements with diabetes have been observed in many research studies ${ }^{(5)}$. The proposed mechanism of trace elements enhancing insulin action includes activation of insulin receptor sites and serving as co-factors or components for enzyme systems involved in glucose metabolism ${ }^{(6,7)}$.

Zinc serves as an essential co-factor for more than 200 enzymes, many of which regulate the metabolism of carbohydrates, lipids, and proteins. Insulin itself is believed to be stored in an inactive form of zinc crystals ${ }^{(8)}$. Zinc ions in the secretory granules of cells are known to glue insulin $\beta$ molecules, creating somatically stable hexamers. When the secretory granules open to the surface, the zinc ions pressure decreases rapidly and $\mathrm{pH}$ levels change from acid to physiological levels, which results in free insulin monomers and zinc ions will be released from the pancreas ${ }^{(9)}$. Thus zinc is required for insulin synthesis and storage (10). There is accumulating evidence that the metabolism of zinc is altered in type 1 diabetes and that zinc might have specific roles in the pathogenesis and progress of this disease ${ }^{(\mathbf{1 1})}$.

Copper is the third most abundant mineral in the human body. Copper is present in the body combined with various enzymes to form metalloenzymes such as ceruloplasmin, SOD, These enzymes play a major role in redox reactions, such as superoxide dismutase which plays key role in antioxidant defense. Copper is associated with altered glucose metabolism through the stimulation of glycation and release of copper ion enhancing the oxidative damage ${ }^{(12)}$. It is known that copper plays an important role in the development and maintenance of immune system function (13). Proposed mechanisms of enhancement of insulin action by trace elements include activation of insulin receptor sites, serving as cofactors or components for enzyme systems which are involved in glucose metabolism, increasing insulin sensitivity and acting as antioxidants for preventing tissue peroxidation (14). Trace elements participate in production of reactive oxygen species (ROS), which contribute to oxidative stress. Oxidative stress contributes to the pathogenesis of many diseases including DM. Previous studies have shown that copper causes oxidative stress. Copper acts as a prooxidant and may participate in metal catalyzed formation of free radicals. The increased production of free radicals is likely to be associated with development of type $2^{(15)}$, it is also manifested that some reactive oxygen species (ROS) are produced during diabetes due to imbalance of essential metals. This oxidative stress might decrease the insulin gene promoter activity and mRNA expression in pancreatic islet cells due to hyperglycemic condition ${ }^{(16)}$.

\section{Materials and Methods}

\subsection{Study design:}

Cross-sectional study was conducted at Kassala teaching hospital during the period from March to October 2017, diabetic type 2 patients (30) and control (20), with aged between 20-60 years. 


\subsection{Sampling:}

Veinpencher Blood samples were collected from all participants, samples were left at room temperature and then serum were obtained by centrifugation at $3000 \mathrm{rpm}$ for $10 \mathrm{~min}$, serum used for measure of copper and zinc.

\subsection{Ethical consideration:}

The study was approved by the local ethics committee of Kassala University. All participants were informed by the aim of study after signed written informed consent. Sample and clinical information were used anonymously.

\subsection{Estimation of copper by atomic absorption:}

Principle: The electron of the atom promoted to higher orbital's (excited state) for a short period of time by absorbing a defined quantity of energy. The amount of energy (wave length) is specific to a particular electron transition in a particular element. The radiation measured by using detector and the absorbance is converted to analyze concentration or mass using Bear Lamber low determination of cupper $1 \mathrm{ml}$ of serum diluted with $1 \mathrm{ml}$ of distal water wave length $324.8 \mathrm{~nm}$.

\subsection{Estimation of zinc by atomic absorption:}

Principle: The electron of the atom promoted to higher orbital's (excited state) for a short period of time by absorbing a defined quantity of energy. The amount of energy (wave length) is specific to a particular electron transition in a particular element. The radiation measured by using detector and the absorbance is converted to analyte concentration or mass using Bear Lamber low ${ }^{(17)}$. For determination of zinc $1 \mathrm{ml}$ of serum diluted with $5 \mathrm{ml}$ of distal water wave length $213.9 \mathrm{~nm}$.

\subsection{Statistical analysis:}

Data from all patients were presented as percentage and (mean $\pm \mathrm{SD})$, differences between means of patients and control groups were considered statistically significant with p-value threshold $<0.05$ using independent $\mathrm{T}$-test.

\section{Results}

\subsection{Graf of Concentration of age Diabetic Patients:}

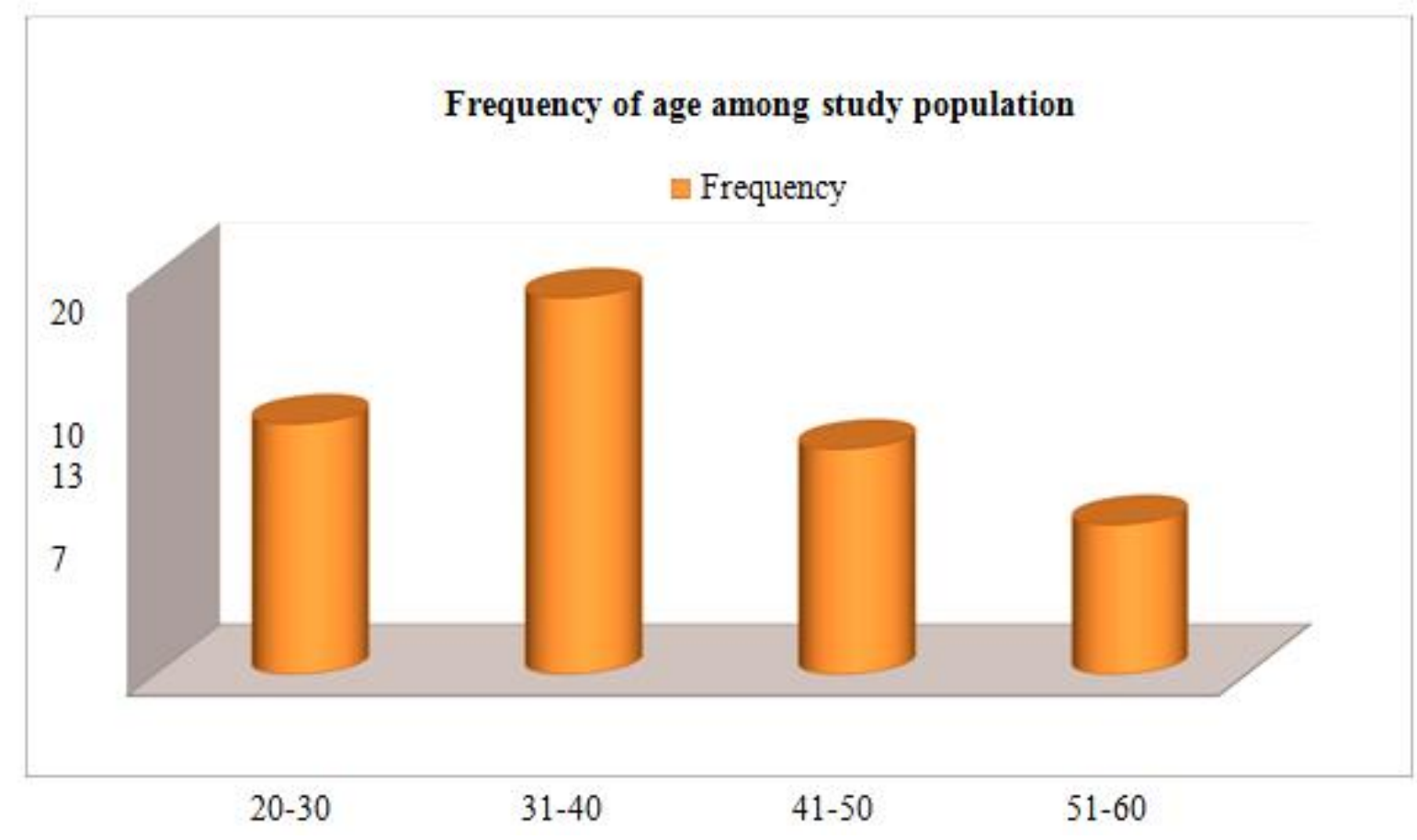


Int. J. Curr. Res. Med. Sci. (2017). 3(10): 42-47

3.2 Table (1) concentration of zinc level in diabetic type 2 patient versus control group

\begin{tabular}{|l|c|c|c|}
\hline Variable & $\begin{array}{c}\text { Case } \\
(\text { Mean } \pm \text { SD) }\end{array}$ & $\begin{array}{c}\text { Control } \\
(\text { Mean } \pm \text { SD) }\end{array}$ & P.value \\
\hline Zinc & $0.14067 \pm 0.086293$ & $0.65550 \pm 0.149663$ & 0.007 \\
\hline
\end{tabular}

$*$ Results expressed as means \pm SD

*significant different consider as $P$.value $\leq 0.05$

3.3 Table (2) concentration of copper level in diabetic type 2 patient versus control group

\begin{tabular}{|l|c|c|c|}
\hline Variable & $\begin{array}{c}\text { Case } \\
(\mathbf{M e a n} \pm \text { SD) }\end{array}$ & $\begin{array}{c}\text { Control } \\
(\mathbf{M e a n} \pm \text { SD) }\end{array}$ & P.value \\
\hline Copper & $0.16653 \pm 0.067793$ & $0.78370 \pm 0.128997$ & 0.0120 .012 \\
\hline
\end{tabular}

*Results expressed as means $\pm \mathrm{SD}$

*significant different consider as $P$.value $\leq 0.05$

\section{Discussion}

Diabetes pathogenesis is considered multifactorial, and the physiological role of copper and zinc has been implicated in the development and progress of the disease ${ }^{(18)}$. the serum levels of zinc and copper in type 2 diabetes and control groups were determined in this study and related to the age and glycemic status.

The present study found that, there was significant decrease in mean concentration of zinc in patients with diabetic type 2 in comparison with control groups with $P$-value 0.007 . This finding agreed with previous study by Anetor et al ${ }^{(19)}$ and Al-Maroof and Al-Sharbatti ${ }^{(20)}$. Which report that, the mean serum zinc level was significantly lower in diabetics' type 2 as compared to control subjects, the possible explanation of the observed hypozincemia in diabetes is hyperzincuria which occurs as a result of hyperglycemia, disrupting the proper metabolism of trace elements.

The study also revealed that copper levels are increased in type 2 diabetes with $P$-value 0.012 . The increased levels of copper in the diabetic patients compared with normal human subjects, this finding agreed with previous study by earlier reports ${ }^{(18,21)}$. The increase in the copper levels in patients with type 2 diabetes might be attributed to hyperglycemia, stimulating glycation, which results in the formation of highly reactive oxidants that can lead to tissue damage

\section{Conclusion}

Altered levels of trace elements $\mathrm{Zn}, \mathrm{Cu}$ are found to be important predisposing factors for diabetic patients for developing complications. From the present study it may be concluded that altered levels of trace elements like zinc and copper may have a role in the pathogenesis and progression of T2DM. The decreased blood levels of $\mathrm{Zn}$ and increased blood levels of $\mathrm{Cu}$ as have been found in present study can be utilized for the screening, diagnosis and management of diabetes mellitus. However this observation requires further study.

Because of important role of trace elements like zinc and copper in diabetes mellitus, it is suggested that an adequate supply of these substances in the diet of diabetic patients can be beneficial in the long term management of diabetic patients, and further studies in this field are recommended. 


\section{References}

1. Lefèbvre P. Diabetes yesterday, today and tomorrow. The action of the International Diabetes Federation. Rev Med Liege 2005;60:(56):273-7.

2. Khan A, Safdar M. Role of diet, nutrients, spices and natural products in diabetes mellitus. Pak J Nutr 2003; 2: 1-12.

3. Koda-Kimble MA, Carlisle BA. Diabetes mellitus. In:young LY, Koda-Kimble MA, Kradjan WA, Guglielmo BJ, editors. Applied therapeutics: the clinical use of drugs. 6th ed. Vancouver (WA): Applied Therapeutics 1995;48:481-5.

4.Garcia MJ, McNamara PM, Gordon T, Kannel WB. Morbidity and mortality in diabetics in the Framingham population: sixteen year follow-up study. Diabetes. 1974; 23: 105-111.

5. Nourmohammadi I, Shalmani IK, Shaabani M, Gohari,L. (2000). Zinc, copper, chromium, manganese and magnesium levels in serum and hair of insulin-dependent diabetics. Arch Iranian Med 2000; 2: 88-100.

6. Murray RK, Grannner PA, Rodwell VW (Eds). Metabolism of carbohydrates. In Harpers Biochemistry. 25th ed. Appleton and Lange, 2001: pp 190-5.

7. Vincent J. Quest for the molecular mechanism of chromium action and its relationship to diabetes.

8. Singh RB, Niaz MA, Rastogi SS, et al. Current zinc intake and risk of diabetes and coronary artery disease and factors associated with insulin resistance in rural and urban populations of North India. J Am Coll Nutr 1998; 17: 564-70.

9. Sondergaard G, Stoltenberg M, Flyvbjerg A, et al. Zinc ions in beta cells of obese, insulin resistant and type II diabetic rats traced by autometaallography. J Trace Elem Med Bio 2003; 11: 1147.

10. Chausmer AB. (1998). Zinc, insulin and diabetes. J Am Coll Nutr 1998; 17: 109-15.

11. Women Health Document. (2005). http://womenshealth.about.com/cs/ highbloodpressur/ a/ hypertentionhbp.htm
12. Nudrat Anwar Zuberi, Sabeela Noor, Fasiha Fatima, Khalilullah, and Muhammad Iltaf, Zinc and Copper Levels Fluctuate with Altered Glucose Homeostasis. Pakistan Journal of Medicine and Dentistry. 2013, Vol. 2(03): 3-7 13. Failla M. L., Hopkins R.G., Is low copper status immunosuppressive? NutrRev, 1998, 56:59-64,

14. Praveeena S., Sujatha Pasula, and K. Sameera. Trace elements in diabetes mellitus. Journal of Clinical and Diagnostic Research. Sep 2013; 7(9): 1863-1865.

15. Supriya, Shrabani Mohanty, Venkata Bharatkumar Pinnelli, Roopamurgod, Raghavendra Ds. Evaluation of serum copper, magnesium and glycated haemoglobin in type 2 diabetes mellitus. Asian Journal of Pharmaceutical and Clinical Research., Vol 6, Issue 2, 2013, 188-190

16. Jiang R, Manson JE, Meigs JB, Ma J, Rifai N, $\mathrm{Hu} \mathrm{FB}$, Body iron stores in relation to risk of type 2diabetes in apparently healthy women. Us national library of medicine national institutes of health. 2004, 291(6):711-717.

17. G. P. Butrimovitz and W. C. Purdy, Anal, Chim. Acta. 1977, 94, 63.

18. Zargar AH, Bashir MI, Masoodi SR, et al. Copper, zinc and magnesium levels in type-1 diabetes mellitus. Saudi Med J 2002; 23: 539-42.

19. Anetor JI, Senjobi A, Ajose OA, Agbedana EO. Decreased serum magnesium and zinc levels: artherogenic implications in type-2 diabetes mellitus in Nigerians. Nutr

20. Al-Maroof RA, Al-Sharbatti SS. Serum zinc levels in diabetic patients and effect of zinc supplementation on glycemic control of type-2 diabetics: Saudi Med J 2006; 27: 344-50.

21. Walter RM, Uriu-Hare JY, Olin KO, et al. Copper, zinc, manganese, and magnesium status and complications of diabetes mellitus. Diabetes Care 1991; 14: 1050-6.

22. Singal PK, Khaper N, Palace V, Kumar D. The role of oxidative stress in the genesis of heart disease. Cardiovasc Res 1999; 40: 426-32. 
Int. J. Curr. Res. Med. Sci. (2017). 3(10): 42-47

23. Zelko IN, Mariani TJ, Folz RJ. Superoxide dismutase multigene family: a comparison of the CuZn-SOD (SOD1), Mn-SOD (SOD2), and ECSOD (SOD3) gene structures, evolution, and expression. Free Radic Biol Med 2002; 33: 33749.

\begin{tabular}{|c|l|}
\hline \multicolumn{2}{|c|}{ Access this Article in Online } \\
\hline 品 & $\begin{array}{l}\text { Website: } \\
\text { www.ijcrims.com }\end{array}$ \\
\cline { 2 - 2 } & $\begin{array}{l}\text { Subject: } \\
\text { Quick Response Code }\end{array}$ \\
\hline
\end{tabular}

How to cite this article:

Mubarak Eissa Musa, Abdaleelah ALshaikh Koko, Sara Muawia Mohammed, Esraa Saif ALdean Ibrahim, Abdelrahman Mohamed Sid Ahmed, Khadega Suleiman Mohammed Zarroug, Hutheiefa Ibrahim Younis Mohammed, Rowa ALaa ALdeen Hussein Ahmed. (2017). Serum Copper and Zinc levels in Type 2 Diabetes Mellitus Patients in Kassala State. Int. J. Curr. Res. Med. Sci. 3(10): 42-47. DOI: http://dx.doi.org/10.22192/ijcrms.2017.03.10.008 